\title{
Management Accounting
}


MANAGEMENT ACCOUNTING

A Review of

Contemporary

Developments

Second Edition

Robert W. Scapens

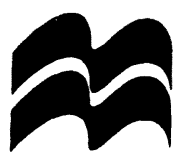

MACMILLAN 
(C) Robert W. Scapens 1985, 1991

All rights reserved. No reproduction, copy or transmission of this publication may be made without written permission.

No paragraph of this publication may be reproduced, copied or transmitted save with written permission or in accordance with the provisions of the Copyright, Designs and Patents Act 1988, or under the terms of any licence permitting limited copying issued by the Copyright Licensing Agency, 33-4 Alfred Place. London WC1E 7DP.

Any person who does any unauthorised act in relation to this publication may be liable to criminal prosecution and civil claims for damages.

First edition 1985

Reprinted 1987, 1989 (twice), 1990

Second edition 1991

Published by

MACMILLAN EDUCATION LTD

Houndmills, Basingstoke, Hampshire RG21 2XS

and London

Companies and representatives

throughout the world

British Library Cataloguing in Publication Data

Scapens, Robert (Robert William) 1946-

Management accounting: a review of contemporary

developments. - 2nd ed.

1. Management accounting

I. Title

658.1511

ISBN 978-0-333-55353-4

ISBN 978-1-349-21348-1 (eBook)

DOI 10.1007/978-1-349-21348-1

$\begin{array}{lllllll}10 & 9 & 8 & 7 & 6 & 5 & 4\end{array}$

$\begin{array}{llllllll}06 & 05 & 04 & 03 & 02 & 01 & 99 & 98\end{array}$ 
In memory of W. R. Scapens 


\section{Contents}

Preface to the First Edition xi

Preface to the Second Edition xiii

PART 1 MANAGEMENT ACCOUNTING: THEORY AND PRACTICE

1 Introduction 3

2 The Conventional Wisdom 7

2.1 The Rise of Management Accounting 7

2.2 The Scope of Management Accounting 10

2.3 Planning 12

2.4 Cost Classifications 15

2.5 Control 16

2.6 Costing 19

2.7 Divisionalised Organisations 21

2.8 Some Implied Assumptions of Management Accounting 22

3 Management Accounting Practice 26

3.1 The Gap Between Theory and Practice 26

3.2 Management Accounting Case Studies 29

3.3 Explaining the Gap 33 


\section{PART II EXTENSION OF QUANTITATIVE MODELS}

$1 \quad$ Statistical Regression Analysis 39

4 4.1 The Use of Regression Analysis 40

4.2 The Least Squares Regression Model 41

4.3 Some Other Problems 46

4.4 Testing the Adequacy of the Model 47

4.5 Use of the Model 52

4.6 Multiple Regression 54

4.7 Some Concluding Remarks 62

Cost-Volume-Profit Analysis 65

5.1 The Simple Model 66

5.2 Assumptions 68

5.3 Multiproduct C-V-P Analysis 70

5.4 The Simple Model with Uncertainty 72

5.5 Limitations 74

5.6 Multiproduct C-V-P Analysis Under Uncertainty 76

5.7 Uncertainty in Other Variables 78

5.8 Some Final Points 79

6 Variance Investigation Models 81

6.1 The Decision Theory Approach 82

6.2 Determining Probabilities 84

6.3 An Illustration 85

6.4 Bayes' Theorem 86

6.5 Discussion 90

\section{PART III INFORMATION COSTS AND BENEFITS}

\section{$7 \quad$ Value of Information 97}

7.1 Information Costs 97

7.2 The Value of Information 99

7.3 An Ice-cream Manufacturer 102

7.4 The Value of Imperfect Information 106

7.5 Discussion 112

8 Information Economics 114

8 8.1 The Ice-cream Manufacturer's Problem 115 
8.2 The Role of Information 118

8.3 Bayes' Theorem 119

8.4 Value of Information 121

8.5 The Selection of an Information System 122

8.6 Discussion 124

\section{(9) Simplified Models and Empirical Studies 127}

9.1 Revisions to the 'Complete' Analysis 128

9.2 Form of Model Simplification 130

9.3 Illustration 131

9.4 Implications for Empirical Work 134

9.5 A Change of Emphasis 137

9.6 Some Comments on Behavioural Accounting Research 140

\section{PART IV CURRENT AND FUTURE DEVELOPMENTS}

Agency Theory and Management Accounting 145

10.1 The Agency Theory Framework 147

10.2 Information Asymmetry 150

10.3 Limitations of the Agency Model 151

10.4 Some General Implications of Agency Theory 153

10.5 Specific Management Accounting Implications of Agency Theory 156

10.6 The Contribution of Agency Theory 159

10.7 Possible Reasons for Cost Allocations 162

11 Cost Allocation Models 164

1111.1 The Textbook Approach 165

11.2 Allocations of Joint Costs 167

11.3 Allocations of Common Costs 174

11.4 Other Approaches 180

12 Activity-Based Costing 183

12.1 The Modern Production Environment 184

12.2 Activity-Based Costing 187

12.3 An Illustration 191

12.4 Activity-Based Costing in Action 198

12.5 Potential and Limitations 205 
12.6 When to Use Activity-Based Costing 207

12.7 The Future of Activity-Based Costing 209

13 Some Possible Future Developments 212

13.1 Crisis in Management Accounting? 215

13.2 The Dual Nature of Management Accounting 217

13.3 Some Implications of the Change of Emphasis 219

13.4 Directions for the Future 221

References 223

Index $\mathbf{2 3 2}$ 


\section{Preface to the First Edition}

In 1982 I wrote a survey paper on management accounting for the Economic and Social Research Council (ESRC - at that time, SSRC). My objective in writing that paper was to survey the development of management accounting in the academic literature over the preceding twenty years or so in an attempt to assess the current state-of-the-art. The paper reviewed contemporary developments in management accounting research in quite broad terms and when I decided to use the general themes of the survey in my undergraduate teaching, I found it necessary to give students a number of lectures to introduce them to the concepts and techniques which have been discussed in the research literature. This book has arisen out of these lectures.

Readers who are familiar with the management accounting research literature are urged to read the survey paper, which has now been published along with two other ESRC-commissioned surveys in Management Accounting, Organizational Theory and Capital Budgeting by R. W. Scapens, D. T. Otley and R. J. Lister (Macmillan/ESRC, 1984). This present book is intended for readers who have not explored the research literature in any depth, but have some knowledge of standard textbook treatments of the subject. The contents of the book are aimed at second/third year students of management accounting and others who want to understand the directions of contemporary management accounting research. 
It is assumed that the reader has had at least an introductory course in management accounting and is familiar with the topics typically covered in introductory textbooks. But a reader who has studied or is currently studying an intermediate management accounting textbook will also find this book very relevant. An attempt has been made to limit the complexity of highly mathematical topics - where mathematics are used they are kept as simple as possible and the interested reader is referred to more detailed treatments elsewhere. In general, emphasis is given to the interpretations and conclusions which can be drawn from mathematical analyses, rather than to the form of the analyses themselves.

No attempt is made to achieve a comprehensive coverage of all research which can be described as being within the field of management accounting. Certain important topic areas have been selected to illustrate the general nature of contemporary developments in management accounting research. Having completed the book, the reader should have an understanding of current academic thought in management accounting, a knowledge of where it has come from, and some ideas as to where it might lead.

I would like to express my gratitude to the ESRC for commissioning the survey paper which has led eventually to this book. In addition, my thanks are due to Professor Mike Bromwich, who first suggested that I should expand my survey paper into a book, and whose comments, criticisms and advice in the editorial process have contributed greatly to the end result. Mention should also be made of a number of my students who offered critical comments on earlier drafts. Finally, I would like to express my special thanks to my wife, Maureen, for her support and encouragement and for the many hours she spent word processing the material for this book. 


\section{Preface to the Second Edition}

In the five years since the first edition was published management accounting research has received considerable attention, particularly in the professional literature. The claims of Professors Johnson and Kaplan that management accounting has lost its relevance in the modern technological environment and is failing to give managers the information they need to compete in highly competitive world markets has created an atmosphere of crisis in management accounting circles. In this second edition these claims are discussed and a proposal to introduce a new system of cost accounting, called activity-based costing, is evaluated. In addition, reviews of other areas of accounting research are brought up to date.

The descriptions of management accounting practice in Chapter 3 have been extended to encompass the various case studies which have been published in recent years. But the major changes have been in Part IV, Current and Future Developments (Chapters 10-13), which has been revised and extended to include the developments which have taken place over the last five years. Chapter 10 (Agency Theory and Management Accounting) and Chapter 11 (Cost Allocation Models) have been revised and their order reversed. Chapter 12 is a new chapter which describes activity-based costing and Chapter 13 (previously Chapter 12) has been extended to evaluate the crisis in management accounting. 
Other parts of the book are substantially unchanged, although amendments have been made in response to suggestions made by users of the first edition. In particular, I am grateful for comments received from my own students and from John Benzies, who read the first edition on to tape for the RNIB Student Tape Library. I would also like to thank my colleagues Trevor Hopper and Linda Lewis for commenting on the new material for the second edition. Finally, I want to thank again my wife, Maureen, for her continuing support and for her word processing.

June 1990

Robert W. Scapens 